\title{
sciendo
}

\section{A Meta-Analysis on the Effect of Complex Training on Vertical Jump Performance}

\author{
by \\ Jeffrey Pagaduan ${ }^{1}$, Haris Pojskic ${ }^{2}$
}

\begin{abstract}
Complex training $(C T)$ is a strength training intervention performed by completing all the sets of a resistance exercise followed by a series of high-velocity/plyometric exercise/s. The purpose of this novel study was to conduct a metaanalysis on the effect of CT on vertical jump (VJ) performance. Five electronic databases were searched using terms related to $C T$ and the VJ. Studies needed to include randomized trials comparing CT with traditional resistance training

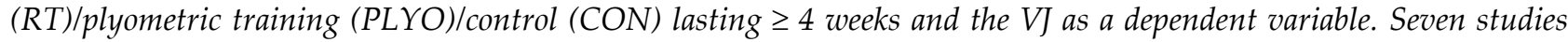
qualified for the meta-analysis with two studies differentiating VJ performance from CT and RT, two studies comparing VJ performance of CT and PLYO, and two studies establishing the difference in VJ performance between CT and CON. Results indicated similar improvement in VJ performance from CT and RT $(p=0.88)$. On the other hand, greater VJ performance in CT than PLYO was identified ( $E S=0.86 ; 95 \%$ CI $0.24,1.47 ; p=0.01$ ). CT also showed significantly greater enhancement in VJ compared to CON $(E S=1.14 ; 95 \%$ CI 0.60, 1.68; $p<0.01)$. In conclusion, CT can serve as alternative training from RT in improving VJ performance. On the other hand, CT is a better option in VJ enhancement than PLYO and CON.
\end{abstract}

Key words: vertical jump, countermovement jump, strength training, plyometrics.

\section{Introduction}

Designing strength training programs for power enhancement has been a constant challenge among practitioners. In the recent decade, complex training $(\mathrm{CT})$ has been receiving a notable attention as one of the interventions for improving power (Carter and Greenwood, 2014; Ebben, 2002; Lesinski et al., 2014). CT is a strength training scheme that integrates resistance training and high-velocity/plyometric training in a single session. One variation of CT is performed by completing all the sets of a resistance exercise followed by a series of high-velocity/plyometric exercise/s (Ebben, 2002). The purpose of this novel study was to administer a meta-analysis on the effect of CT on vertical jump (VJ) performance.

\section{Methods}

Search Strategy

PRISMA guidelines for literature of databases (GoogleScholar, SPORTDiscus, World of Science, SpringerLink, and PubMed) were utilized from all time points until January 30, 2018 (Moher et al., 2009). The search terms and Booleans included (complex training) OR (contrast training) OR (combined weight training and plyometrics) OR (combined strength training and plyometrics) OR (combined resistance training and plyometrics) AND (vertical jump or jump performance). Manual searches from references were also carried out. Inclusion criteria were: 1) randomised trials peer-reviewed in English; 2) CT intervention that compared any resistance training (RT) or plyometric training (PLYO) or a control (CON) wherein COM involved completing all the sets of a resistance exercise succeeded by a series of high velocity/plyometric exercises; 3) availability of pre and post VJ data executed with a countermovement; and, 4) training intervention performed at least twice a week with duration of $\geq$

\footnotetext{
1 - College of Health and Medicine, School of Health Sciences, University of Tasmania - Newnham Campus, Tasmania, Australia.
} 2 - Department of Sports Science, Linnaeus University, Kalmar, Sweden. 
4 weeks.

\section{Data Extraction}

A single investigator (JP) who is a certified strength and conditioning specialist with more than 10 years of experience and holds a master's degree in applied sport and exercise science assessed the eligibility of studies. In the first stage, titles and abstracts of identified articles were examined for relevance. Reference lists of included articles were also checked for possible inclusion. Full-text articles of potential studies were retrieved and assessed individually during the second stage. The second investigator (HP) who is an assistant professor specializing in sports training research independently checked the data extraction administered by JP. Both investigators rated the included studies for 'risk of bias' using an eightpoint scale from the Consolidated Standards of Reporting Trials (CONSORT) statement where each item was answerable by 0 (absently or inadequately described) or 1 (explicitly described and present) (Altman et al., 2001). A score of 0-2 was regarded as having a high risk of bias, 3-5 with medium risk, and 6-8 considered as having a low risk of bias. A consensus between the first and second investigator was reached for any disagreement presented in data extraction and CONSORT output.

\section{Statistical Analysis}

A free meta-analysis tool (RevMan ver 5.3, The Nordic Cochrane Centre, Copenhagen) was utilized to examine VJ height in comparison with COM and RT/CON/PLYO. Standardized mean differences (difference in mean outcomes between groups/standard deviation of the outcome among participants) was used to derive effect size (ES) and interpreted with the following criteria: .2 - small effect; 0.5 - moderate effect; 0.8 - large effect (Cohen, 1988; Zlowodzki et al., 2007).

\section{Results}

The literature search uncovered 1067 potential articles and two articles were identified from reference lists. Removal of duplicates $(\mathrm{n}=$ 345) left 742 articles. After screening of the title and abstracts, 83 articles underwent a more detailed evaluation and led to the exclusion of 76 , thus, leaving 7 articles for meta-analysis (de Villareal et al., 2011; Fayed, 2015; Ferrete et al., 2014; FrancoMárquez et al., 2014; Lyttle et al., 1996; RodríguezRosell et al., 2017; Saeed, 2013). Figure 1 presents the flow diagram of study selection.

CONSORT scores of the seven studies in meta-analysis showed only one study scoring 5 (Rodríguez-Rosell et al., 2017). There were four studies that scored 4 (de Villareal et al., 2011; Ferrete et al., 2014; Franco-Márquez et al., 2014; Lyttle et al., 1996). Lastly, two studies scored 1 (Fayed, 2015; Saeed, 2013). Table 1 displays the CONSORT scores of the studies.

Participants determined in the metaanalysis involved thirty-nine physical education students, 33 regional athletes, and 151 young athletes with CT interventions administered twice to three times a week lasting from 6 to 12 weeks. Two studies compared CT and RT (de Villareal et al., 2011; Rodríguez-Rosell et al., 2017). Two studies differentiated between CT and PLYO (de Villareal et al., 2011; Lyttle et al., 1996), while six studies compared CT and CON (Fayed, 2015; Ferrete et al., 2014; Franco-Márquez et al., 2014; Lyttle et al., 1996; Rodríguez-Rosell et al., 2017; Saeed, 2013). The characteristics of studies are presented in Table 2.

CT vs. RT

There was no significant difference in VJ performance between $\mathrm{CT}$ and $\mathrm{RT}$ at $\mathrm{Z}=0.15, p=$ 0.88 .

CT exhibited a $13.2 \%$ (95\% CI 1.54 to 4.16 $\mathrm{cm})$ improvement in VJ performance. On the other hand, RT showed a $12.5 \%$ (95\% CI 1.39 to $4.21 \mathrm{~cm})$ increase in VJ performance. The funnel plot of CT vs. RT is presented in Figure 2.

CT vs. PLYO

CT posted significantly greater enhancement in VJ performance than PLYO, Z = $4.15, p=0.01, \mathrm{ES}=0.8695 \% \mathrm{CI}[0.24,1.47]$. CT showed a $15.9 \%(95 \%$ CI 2.71 to $6.59 \mathrm{~cm})$ increase in VJ performance, while PLYO posted an $8.89 \%$ (95\% CI 0.84 to $4.66 \mathrm{~cm}$ ) VJ attenuation. The funnel plot of CT vs. PLYO is displayed in Figure 3.

CT vs. CON

CT significantly improved VJ performance compared to $\mathrm{CON}$ at $\mathrm{Z}=4.15, p<0.01, \mathrm{ES}=1.14$ $[0.60,1.68]$. CT improved VJ performance by $8.8 \%$ (95\% CI 1.48 to $4.74 \mathrm{~cm}$ ), whereas CON showed a $2.11 \%(95 \% \mathrm{CI}-0.94$ to $2.06 \mathrm{~cm})$ increase in VJ performance. Figure 4 exhibits the funnel plot of CT vs. CON. Pre and post VJ data from CT and a comparison group is depicted in Figure 4. 


\section{Discussion}

The aim of this novel study was to conduct a meta-analysis on the effect of CT on VJ performance wherein CT was defined as completing all the sets of a resistance exercise succeeded by a series of high-velocity/plyometric exercise/s. Results revealed that CT exhibited similar improvement in VJ performance with RT. On the other hand, CT posted greater enhancement in VJ performance when compared with PLYO. Similarly, CT showed superior VJ gains than CON. Enhancement in VJ performance with CT compared to PLYO/CON may be related to the added stimulus in CT that facilitated postactivation potentiation (PAP) (Gołaś et al., 2016; Robbins, 2005; Sale, 2002). PAP refers to the enhancement of performance from myosin phosphorylation and h-reflex excitation. In relation to this, VJ gains from CT may be related to cellular and hormonal adaptations favourable to power enhancement (Beaven et al., 2011; Labib, 2013). For example, Beaven et al. (2011) presented increased testosterone while enhancement in VJ performance after CT. Labib (2013) documented increased CD34/CD45 immune system stem cell secretion with improvement in the standing long jump after CT (Donovan and Koretzky, 1993; Sidney, 2014). It may be also possible that greater preservation of IIX muscle fibers is achieved with CT than PLYO/CON (Stasinaki et al., 2011). Greater selective recruitment of FTx muscle fibers in CT compared to PLYO/CON may have also occurred (Gołaś et al., 2016). On the other hand, nonsignificant difference in VJ improvement exhibited between CT and RT may point to possible fatigue induced by CT which may have masked possible potentiation effects (Häkkinen, 1993; Wilson et al., 2013).

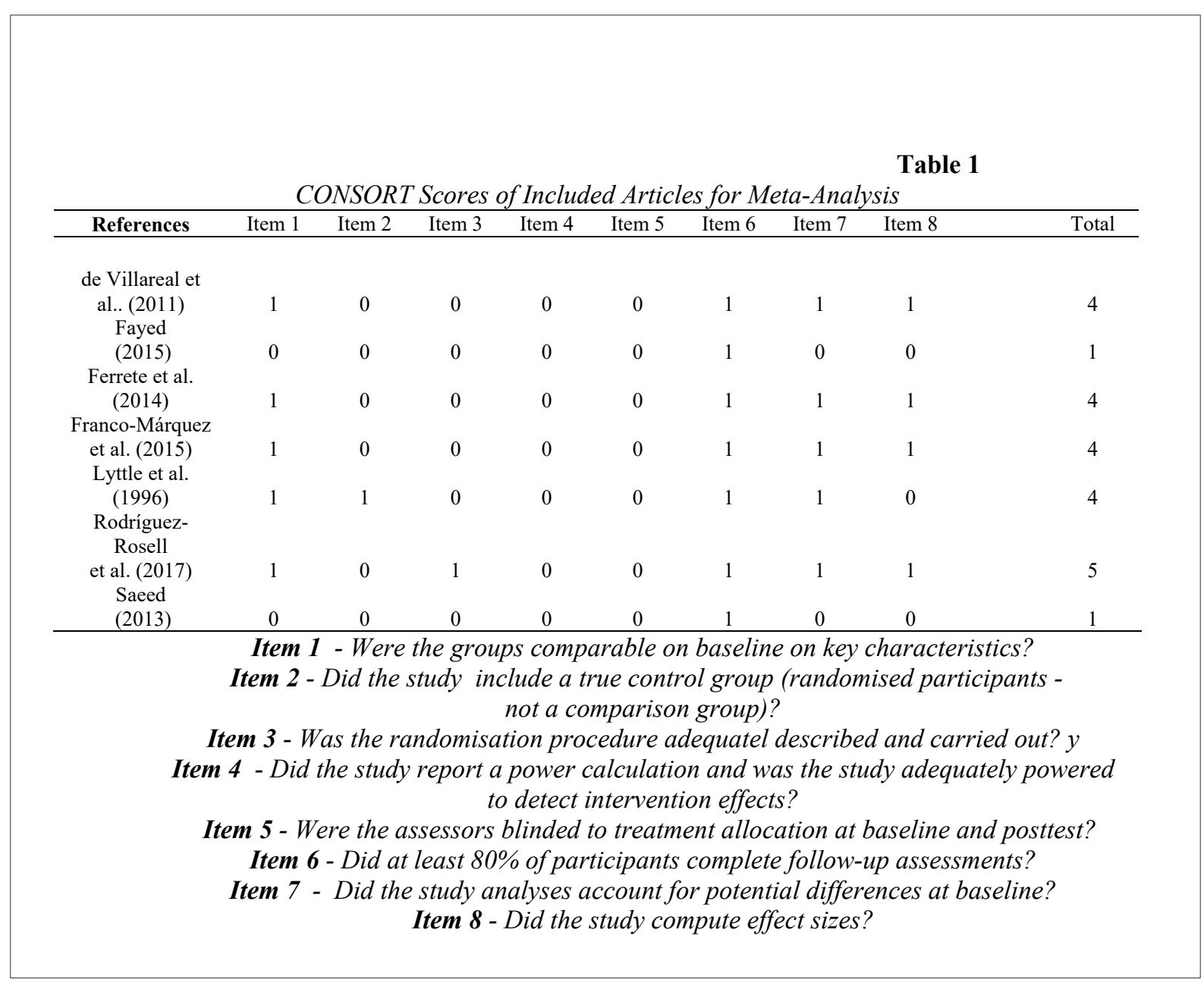




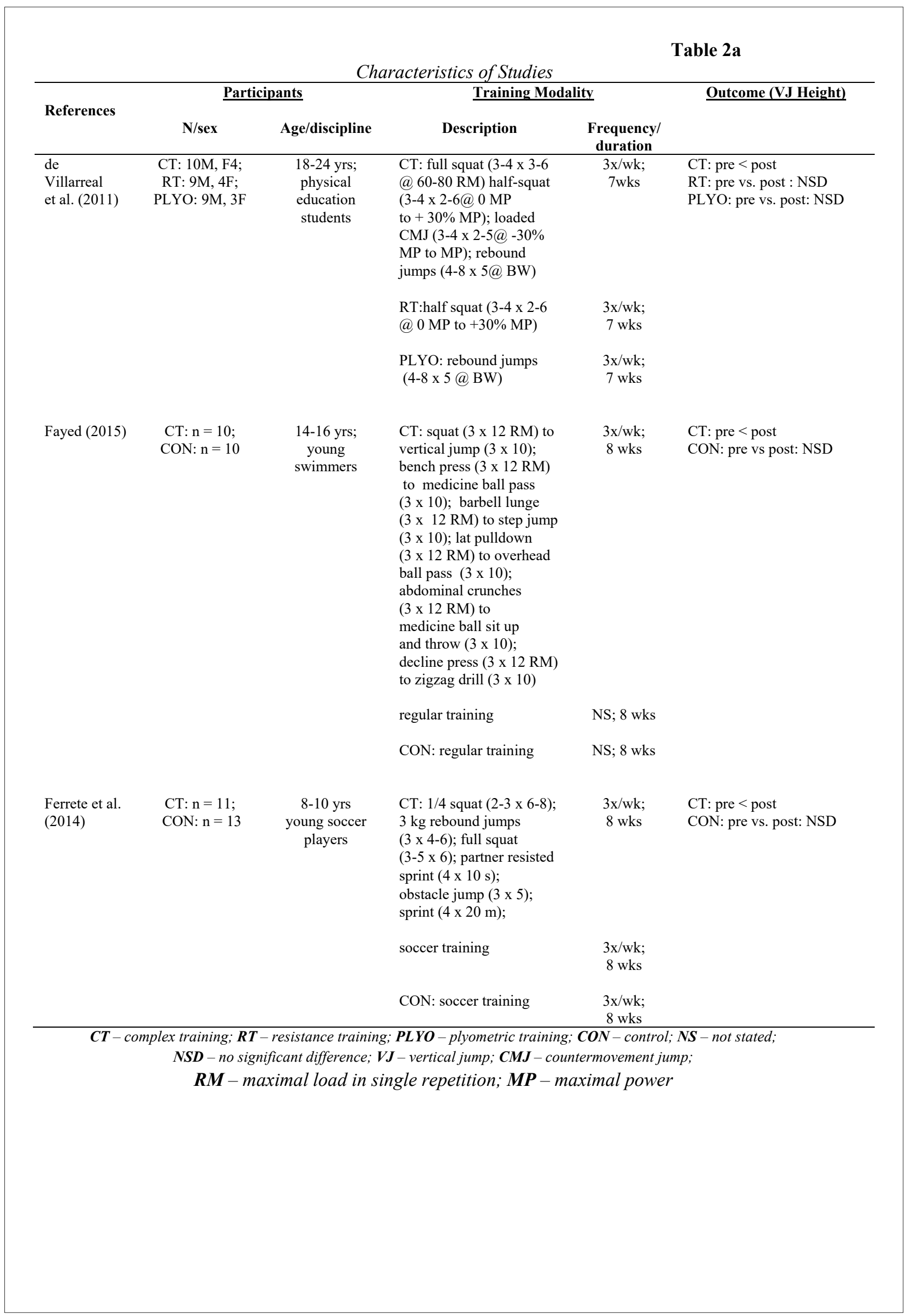




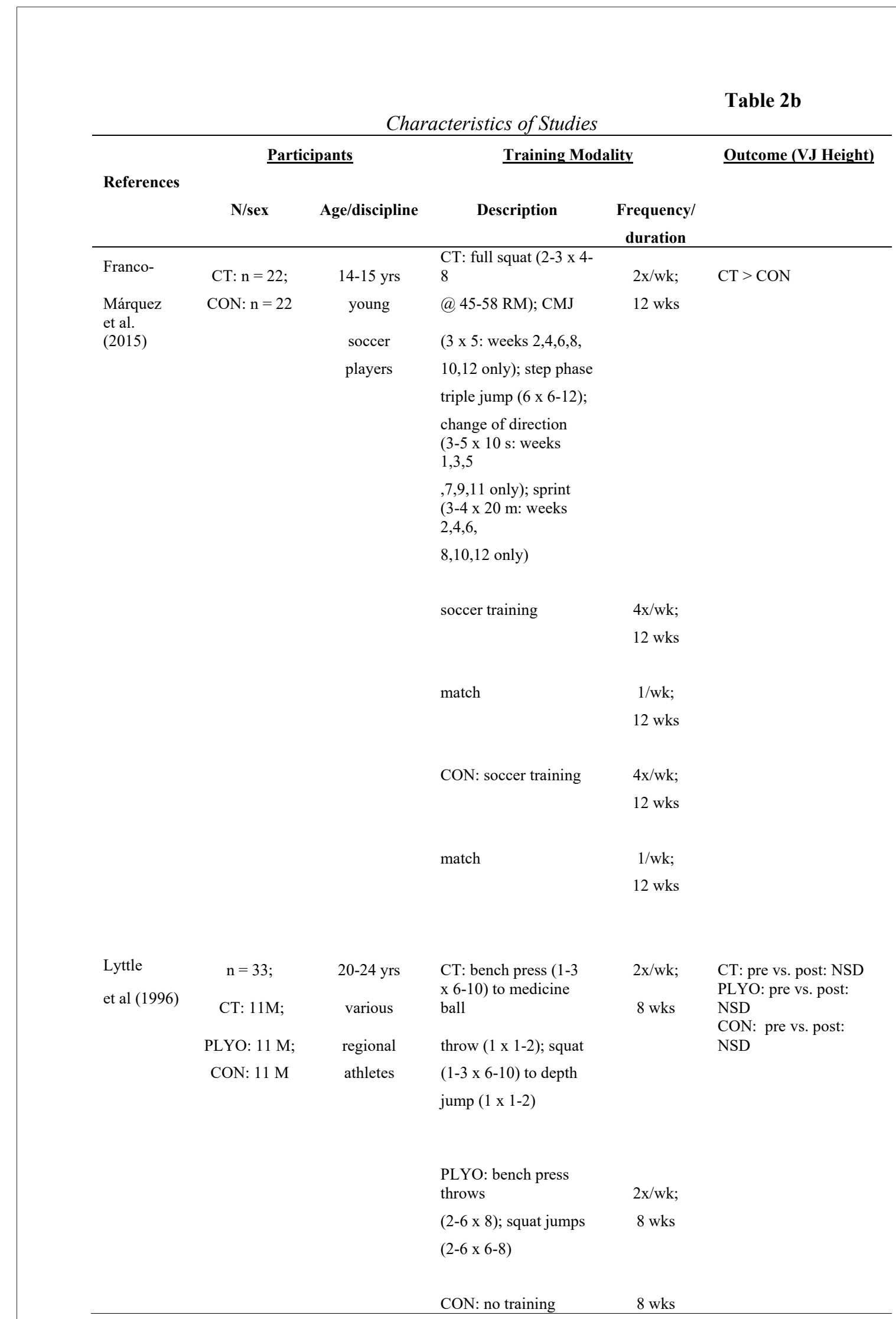


Table 2c

Characteristics of Studies

\begin{tabular}{|c|c|c|c|c|c|}
\hline \multirow{2}{*}{ References } & \multicolumn{2}{|c|}{ Participants } & \multicolumn{2}{|c|}{ Training Modality } & \multirow[t]{2}{*}{ Outcome (VJ Height) } \\
\hline & $N / \operatorname{sex}$ & Age/discipline & Description & $\begin{array}{c}\text { Frequency/ } \\
\text { duration }\end{array}$ & \\
\hline \multirow[t]{8}{*}{$\begin{array}{l}\text { Rosell } \\
\text { et al. (2017) }\end{array}$} & $\begin{array}{l}\text { CT: } 10 \mathrm{M} ; \\
\text { RT: } 10 \mathrm{M} ; \\
\text { CON: } 10 \mathrm{M}\end{array}$ & $\begin{array}{l}\text { semi- } \\
\text { professional } \\
\text { soccer }\end{array}$ & $\begin{array}{l}\text { @ } 45-60 \mathrm{RM}) \text {; CMJ } \\
(3 \times 5) \text {; change of direction } \\
(3-5 \times 10 \mathrm{~s}) \text {; sprint } \\
(3-4 \times 20 \mathrm{~m})\end{array}$ & 6 wks & $\mathrm{CT}>\mathrm{CON}$ \\
\hline & & & soccer training & $\begin{array}{c}4 \mathrm{x} / \mathrm{wk} \\
6 \mathrm{wks}\end{array}$ & \\
\hline & & & match & $\begin{array}{l}1 / \mathrm{wk} \\
6 \mathrm{wks}\end{array}$ & \\
\hline & & & $\begin{array}{l}\text { RT: full squat } \\
(2-4 \text { x 3-6 @ 45-60 RM) }\end{array}$ & $\begin{array}{c}2 \mathrm{x} / \mathrm{wk} \\
6 \mathrm{wks}\end{array}$ & \\
\hline & & & soccer training & $\begin{array}{c}4 \mathrm{x} / \mathrm{wk} \\
6 \mathrm{wks}\end{array}$ & \\
\hline & & & match & $\begin{array}{l}1 / \mathrm{wk} \\
6 \mathrm{wks}\end{array}$ & \\
\hline & & & CON: soccer training & $\begin{array}{l}4 \mathrm{x} / \mathrm{wk} \\
6 \mathrm{wks}\end{array}$ & \\
\hline & & & match & $\begin{array}{l}1 / \mathrm{wk} \\
6 \mathrm{wks}\end{array}$ & \\
\hline \multirow[t]{3}{*}{ Saeed (2013) } & $\begin{array}{c}\mathrm{n}=20 ; \mathrm{CT}: 10 \mathrm{~F} \\
\text { CON: } 10 \mathrm{~F}\end{array}$ & $\begin{array}{c}10-14 \text { yrs } \\
\text { young female } \\
\text { volleyball } \\
\text { players }\end{array}$ & $\begin{array}{l}\text { CT: squat }(3 \times 12 \mathrm{RM}) \text { to } \\
\text { vertical jump }(3 \times 10) \text {; } \\
\text { bench press }(3 \times 12 \mathrm{RM}) \\
\text { to medicine ball pass } \\
(3 \times 10) \text {; barbell lunge } \\
(3 \times 12 \mathrm{RM}) \text { to step jump } \\
(3 \times 10) \text {; lat pulldown } \\
(3 \times 12 \mathrm{RM}) \text { to ovehead } \\
\text { ball pass }(3 \times 10) \text {; } \\
\text { abdominal crunches } \\
(3 \times 12 \mathrm{RM}) \text { to medicine } \\
\text { ball sit up and throw } \\
(3 \times 10) \text {; decline press } \\
(3 \times 12 \mathrm{RM}) \text { to } \\
\text { zigzag drill }(3 \times 10)\end{array}$ & $\begin{array}{l}3 \mathrm{x} / \mathrm{wk} \\
9 \mathrm{wks}\end{array}$ & $\begin{array}{l}\text { CT: pre }<\text { post } \\
\text { CON: pre }<\text { post }\end{array}$ \\
\hline & & & regular training & NS; 9 wks & \\
\hline & & & $\mathrm{CON}$ : regular training & NS; 9 wks & \\
\hline
\end{tabular}


Table 34

VJ Performance in CT, PLYO, RT, and CON

\begin{tabular}{|c|c|c|c|c|c|c|}
\hline \multirow{4}{*}{$\begin{array}{l}\text { RT } \\
\text { de Villarreal et al. (2011) } \\
\text { Rodríguez-Rosell et al. } \\
\text { (2017) }\end{array}$} & \multicolumn{3}{|c|}{$\begin{array}{c}\mathrm{CT} \\
\mathrm{VJ}(\mathrm{cm})\end{array}$} & & \multicolumn{2}{|c|}{$\begin{array}{c}\text { Comparison Group } \\
\qquad \mathrm{VJ}(\mathrm{cm})\end{array}$} \\
\hline & $\mathrm{n}$ & $\begin{array}{c}\text { Pre } \\
\text { Mean } \pm \text { SD }\end{array}$ & $\begin{array}{c}\text { Post } \\
\text { Mean } \pm \text { SD }\end{array}$ & $\mathrm{n}$ & $\begin{array}{c}\text { Pre } \\
\text { Mean } \pm \text { SD }\end{array}$ & $\begin{array}{c}\text { Post } \\
\text { Mean } \pm \text { SD }\end{array}$ \\
\hline & & & & & & \\
\hline & $\begin{array}{l}14 \\
15\end{array}$ & $\begin{array}{l}17.5 \pm 2.60 \\
37.8 \pm 3.90\end{array}$ & $\begin{array}{l}21.2 \pm 2.50 \\
39.8 \pm 4.20\end{array}$ & $\begin{array}{l}13 \\
15\end{array}$ & $\begin{array}{l}16.9 \pm 3.00 \\
36.3 \pm 4.10\end{array}$ & $\begin{array}{l}19.9 \pm 2.90 \\
38.9 \pm 4.70\end{array}$ \\
\hline PLYO & & & & & & \\
\hline de Villarreal et al. (2011) & 14 & $17.5 \pm 2.60$ & $21.2 \pm 2.50$ & 12 & $16.5 \pm 2.80$ & $18.2 \pm 2.90$ \\
\hline Lyttle et al. (1996) & 11 & $52.8 \pm 11.5$ & $58.4 \pm 9.30$ & 11 & $50.8 \pm 9.00$ & $54.6 \pm 8.50$ \\
\hline $\mathrm{CON}$ & & & & & & \\
\hline Fayed (2015) & 10 & $36.5 \pm 1.61$ & $41.2 \pm 2.64$ & 10 & $37.1 \pm 1.75$ & $38.7 \pm 2.82$ \\
\hline $\begin{array}{l}\text { Ferrete et al. (2014) } \\
\text { Franco-Márquez et al. }\end{array}$ & 11 & $22.3 \pm 2.70$ & $\begin{array}{l}23.7 \pm 3.50 \\
36.2 \pm 6.50\end{array}$ & 13 & $20.2 \pm 3.40$ & $\begin{array}{l}20.3 \pm 3.20 \\
33.4+3.70\end{array}$ \\
\hline Lyttle et al. (1996) & 11 & $52.8 \pm 11.5$ & $58.4 \pm 9.30$ & 11 & $49.2 \pm 3.50$ & $49.2 \pm 5.70$ \\
\hline $\begin{array}{l}\text { Rodríguez-Rosell et al. } \\
2017\end{array}$ & 15 & $37.1 \pm 3.80$ & $37.0 \pm 4.20$ & 15 & $37.0 \pm 6.80$ & $36.1 \pm 5.90$ \\
\hline Saeed (2013) & 10 & $22.3 \pm 2.31$ & $24.2 \pm 2.12$ & 10 & $21.1 \pm 3.11$ & $22.8 \pm 2.64$ \\
\hline
\end{tabular}

\section{Table 4}

Subgroup Analysis for CT vs. CON

\begin{tabular}{|c|c|c|c|c|c|}
\hline Group & $\begin{array}{c}\text { Studies } \\
\text { Reference }\end{array}$ & ES $(95 \% \mathrm{CI})$ & $\mathrm{I}^{2}$ & $\begin{array}{c}\mathrm{p}- \\
\text { value }\end{array}$ & $\begin{array}{c}\text { Subgroup } \\
\text { difference } \\
\text { p-value }\end{array}$ \\
\hline $\begin{array}{l}\text { Population } \\
\text { Characteristics }\end{array}$ & & & & & \\
\hline $\begin{array}{l}\text { Age } \\
\geq 18 \text { years } \\
\leq 18 \text { years }\end{array}$ & $\begin{array}{l}\text { (Lyttle et al., 1996; Rodríguez-Rosell et al., } \\
\text { 2017) } \\
\text { (Fayed, 2015; Ferrete et al., 2014; } \\
\text { Franco-Márquez et al. 2015; Saeed, 2013) }\end{array}$ & $\begin{array}{c}1.92(0.60, \\
3.24)\end{array}$ & 74.0 & $<0.01$ & 0.32 \\
\hline $\begin{array}{l}\text { CT Training } \\
\text { Strategy } \\
\text { traditional } \\
\text { non-traditional }\end{array}$ & $\begin{array}{l}\text { (Fayed, 2015; Lyttle et al., 1996; Saeed, } \\
\text { 2013) } \\
\text { (Ferrette et al., 2014; Franco-Márquez et al., } \\
\text { 2015; } \\
\text { Rodríguez-Rosell et al., 2017) }\end{array}$ & $\begin{array}{c}2.12(1.21, \\
3.03)\end{array}$ & 89.0 & $<0.01$ & 0.59 \\
\hline
\end{tabular}




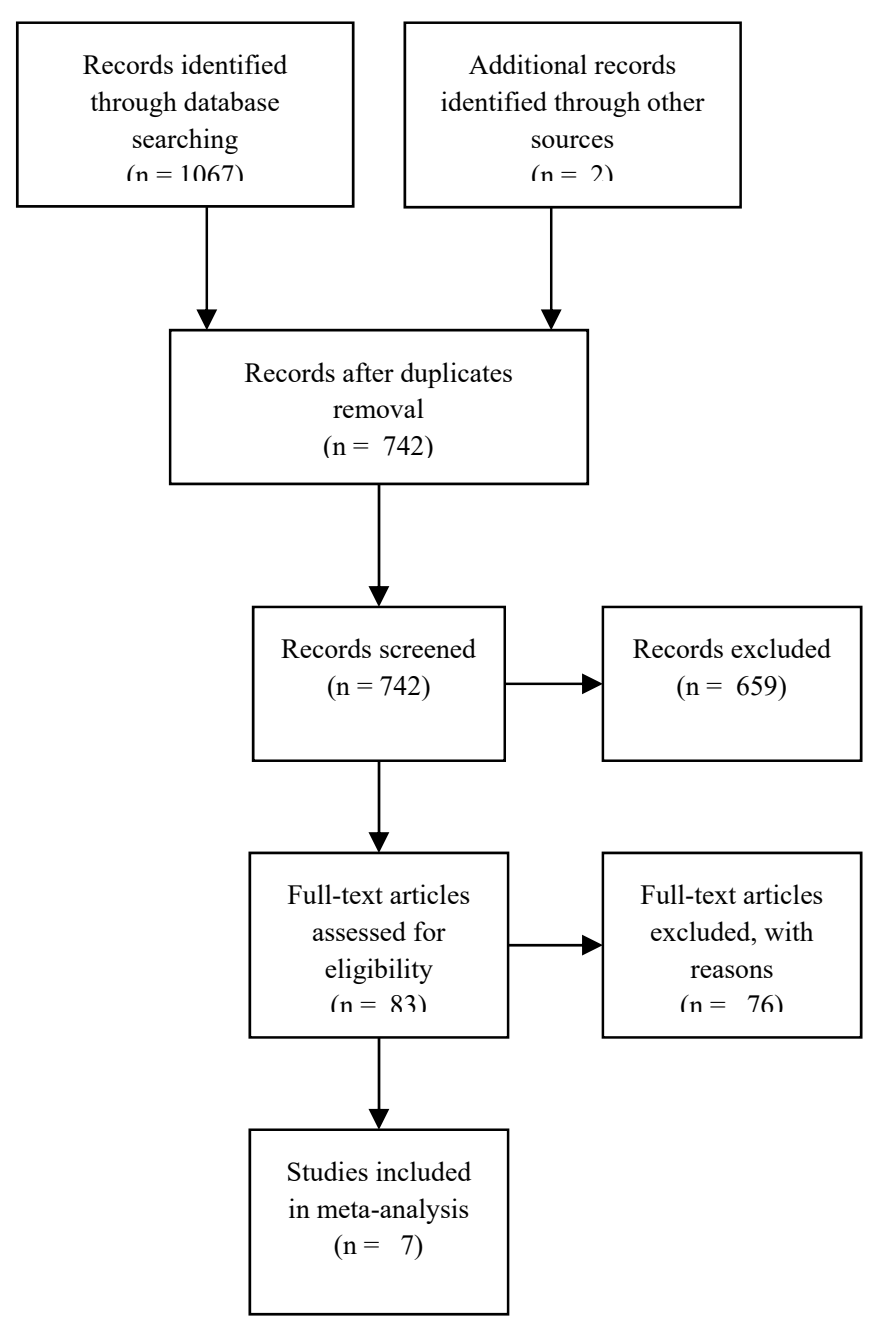

Figure 1

Flow Diagram of the Search Process 


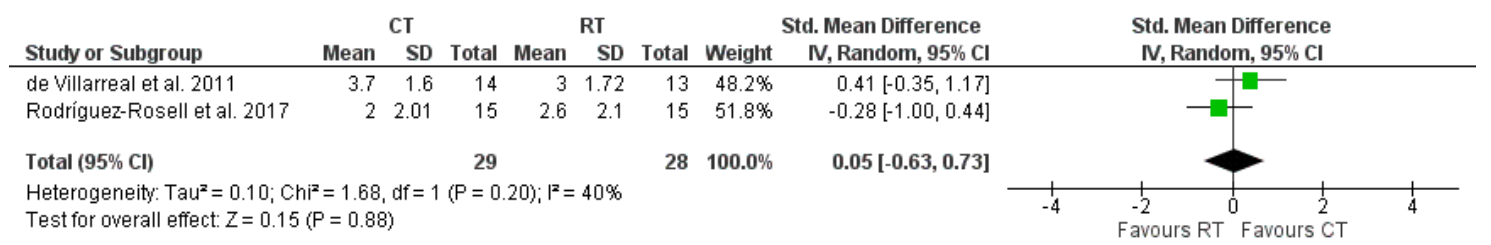

Figure 2

Forest Plot comparing VJ of CT and RT

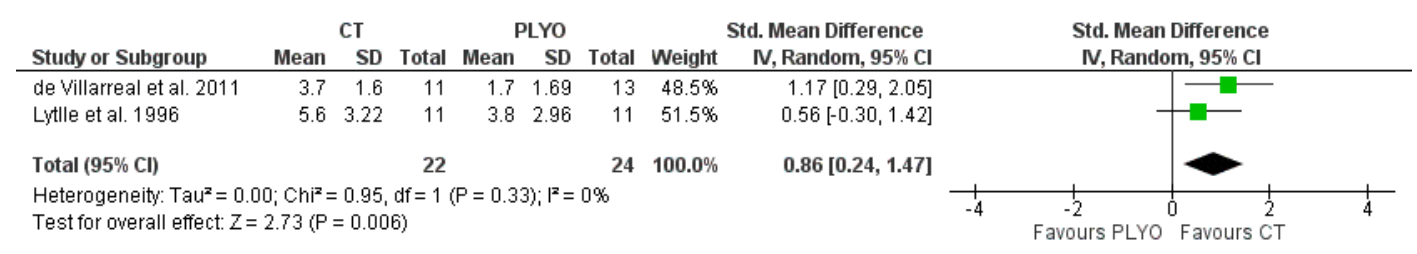

Figure 3

Forest Plot comparing VJ of CT and PLYO

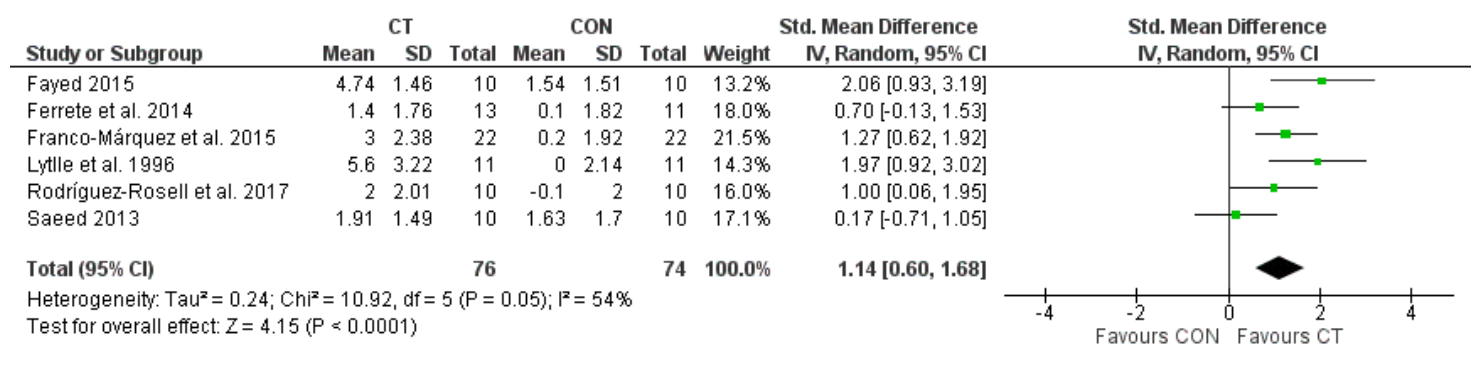

Figure 4

Forest Plot comparing VJ of CT and CON

Subgroup analysis was administered in CT vs. CON to determine possible moderators that led to superior VJ enhancement in CT. Researchers identified age ( $\geq 18$ yrs vs. $\leq 18$ yrs) and CT strategy (traditional vs. non-traditional) as covariates. It was found that both age groups exhibited greater VJ performance following CT than CON. However, no difference in VJ performance was observed between $\geq 18$ yrs and $\leq 18$ yrs in CT vs. CON. Furthermore, traditional and non-traditional CT modalities were analysed. Traditional CT involves a pair of exercises, while non-traditional $\mathrm{CT}$ is executed for 3 or more exercises. Utilizing traditional and non-traditional CT demonstrated greater VJ gains than CON. No difference in VJ enhancement was seen between traditional and non-traditional CT in CT vs. CON. Thus, age and CT strategy moderate VJ improvement in CT vs. CON. Subgroup analysis in CT vs. CON is presented in Table 4.

Limitations of this study are noteworthy of considerations. Firstly, heterogeneity in study designs with a small sample size involved in this study was observed. There was variety in complex training exercises, measurement of the VJ, and training populations. Thus, implications 
for the magnitude of inference from this study are limited. Subgroup analysis was only performed in CT vs. CON with few covariates due to scarcity of studies. Administration of such a method will help provide valuable insights into the findings of this study. The risk of bias of included studies ranged from high to moderate. Additionally, analysis utilizing comparison groups from other strength training schemes of similar volume (e.g. compound training, contrast loading) was not administered. Lastly, it should also be noted that only the VJ executed with countermovement mechanics was included as a dependent variable.

In conclusion, enhancement of the $\mathrm{VJ}$ is achieved interchangeably from CT and RT. However, utilizing CT is more effective than PLYO or $\mathrm{CON}$ in improving $\mathrm{VJ}$ performance.

\section{Acknowledgements}

The authors would like to thank Brad Shoenfeld, PhD for his insights on the meta-analyses. All authors were involved from the project conception, to manuscript preparation.

\section{References}

Altman DG, Schulz KF, Moher D, Egger M, Davidoff F, Gøtzsche PC, Lang T; CONSORT GROUP (Consolidated Standards of Reporting Trials). The revised CONSORT statement for reporting randomized trials; explanation and elaboration. Ann Intern Med, 2001; 17: 663-694

Beaven CM, Gill ND, Ingram JR, and Hopkins WG. Acute salivary hormone responses to complex exercise bouts. J Strength Cond Res, 2011; 25: 1072-1078

Carter J, Greenwood M. Complex training re-examined: review and recommendations to improve strength and power. Strength Cond J, 2014; 36(2): 11-19

Cohen J. Statistical Power Analysis for the Behavioural Sciences. 2nd ed. Hillsdale, NJ: Lawrence Earlbaum Associates; 1988

de Villarreal ES, Izquierdo M, Gonzalez-Badillo JJ. Enhancing jump performance after combined vs. maximal power, heavy-resistance, and plyometric training alone. J Strength Cond Res, 2011; 12: 3274-3281

Donovan JA, Koretzky GA. CD45 and the immune response. J Am Soc Nephrol, 1993; 4(4): 976-985

Ebben WP. Complex training: A brief review. J Sports Sci Med, 2002; 1: 42-46

Fayed H. The effect of complex training on antioxidants, certain physical education and Record level of $50 \mathrm{M}$ crawl swimming for young swimmers. Sci Mov Health, 2015; 15(2): 379-385

Ferrete C, Requena B, Suarez-Arrones L, de Villareal ES. Effect of strength and high-intensity training on jumping, sprinting, and intermittent endurance performance in prepubertal soccer players. J Strength Cond Res, 2014; 28(2): 413-422

Franco-Márquez F, Rodríguez-Rosell D, González-Suárez JM, Pareja-Blanco F, Mora-Custodio R, YañezGarcía JM, González-Badillo JJ. Effects of combined resistance training and plyometrics on physical performance in young soccer players. Int J Sports Med, 2015; 36(11): 906-914

Gołaś A, Maszczyk A, Zajac A, Mikołajec K, Stastny P. Optimizing post activation potentiation for explosive activities in competitive sports. J Hum Kinet, 2016; 52 95-106

Häkkinen K. Neuromuscular fatigue and recovery in male and female athletes during heavy resistance exercise. Int J Sports Med, 1993; 14(2): 53-59

Labib H. Effect of complex training on CD34/CD45 stem cells, certain physical variables and jump shoot performance for female handball. Sci Mov Health, 2013; 13(2): 215-221

Lesinski M, Muehlbauer T, Büsch D, Granacher U. Effects of complex training on strength and speed performance in athletes: a systematic review. Effects of complex training on athletic performance. Sportverletz Sportschaden, 2014; 28(2): 85-107

Lyttle AD, Wilson GJ, Otrowski KJ. Enhancing performance: maximal power versus combined weights and plyometrics training. J Strength Cond Res, 1996; 10(3): 173-179

Moher D, Liberati A, Tetzlaff J, Altman DG; The PRISMA Group. Preferred reporting items for systematic reviews and meta-analyses: the PRISMA statement. Ann Intern Med, 2009; 18: 264-269

Robbins D. Postactivation potentiation and its practical applicability: A brief review. J Strength Cond Res, 2005; 19: $453-458$ 
Rodríguez-Rosell D, Torres-Torrelo J, Franco-Márquez F, González-Suárez JM, González-Badillo JJ. Effects of light-load maximal lifting velocity weight training vs. combined weight training plyometrics on sprint, vertical jump and strength performance in adult soccer players. J Sci Med Sport, 2017; 20(7): 695-699

Saeed KK. Effect of complex training with low-intensity loading interval on certain physical variables among volleyball infants (10-12 ages). Sci Mov Health, 2013; 13(1): 16-21

Sale DG. Postactivation potentiation: role in human performance. Exerc Sport Sci Rev, 2002; 30(3): 138-143

Stasinaki AN, Gloumis G, Spengos K, Blazevich AJ, Zaras N, Georgiadis G, Karampatsos G, Terzis G. Muscle strength, power, and morphologic adaptations after 6 weeks of compound vs. complex training in healthy men. J Strength Cond Res, 2015; 29(9): 2259-2569

Sidney LE, Branch MJ, Dunphy S, Dua HS, Hopkinson A. Concise review: evidence for CD34 as a common marker for diverse progenitors. Stem Cells, 2014; 32(6): 1380-1389

Wilson JM, Duncan NM, Marin PJ, Brown LE, Loenneke JP, Wilson SM, Jo E, Lowery RP, Ugrinowitsch C. Meta-analysis of postactivation potentiation and power: effects of conditioning activity, volume, gender, rest periods, and training status. J Strength Cond Res, 2013; 27(3): 854-859

Zlowodzki M, Poolman RW, Kerkhoffs GM, Tornetta P 3rd, Bhandari M; International Evidence-Based Orthopedic Surgery Working Group. How to interpret a meta-analysis and judge its value as a guide for clinical practice. Acta Orthop, 2007; 78(5): 598-709

\section{Corresponding author:}

\section{Jeffrey Pagaduan}

College of Health and Medicine, School of Health Sciences, University of Tasmania - Newnham Campus,

Tasmania, Australia

E-mail: jcpagaduan@gmail.com 